\title{
Changes in Liver Lipids after Administration of 2-Decanoylamino-3-morpholinopropiophenone and Chlorpromazine
}

\author{
ASHOK V. HOSPATTANKAR ${ }^{1}$, RANGA R. VUNNAM ${ }^{2}$ and NORMAN S. RADIN*, \\ Mental Health Research Institute (Departmont of Psychiatry) and Department of Biological \\ Chemistry, University of Michigan, Ann Arbor, MI 48109
}

\begin{abstract}
The enzyme which forms glucocerebroside, ceramide:UI)P-glucose glucosyltransferase, is inactivated in vitro by a cationic analog of cerebroside, 2-decanoylamino-3-morpholinopropiophenone. $\mathbf{A}$ study of the inhibitor using intraperitoneal injection into young mice showed that the level of the enzyme activity in liver was appreciably lowered between 3 and $6 \mathrm{hr}$ after injection. The activity increased subsequently, overshooting the normal level within $24 \mathrm{hr}$ by about $20 \%$, then returning to normal within the next $24 \mathrm{hr}$. Additional effects observed in liver were an increase in lipid content (primarily in the triglyceride fraction and ceramides) and a decrease in the glucocerebroside level. Body temperature dropped rapidly. Markedly similar effects were produced by injecting chlorpromazine, which was tried in order to reduce the hyperirritability and inhibitory effects on monoamine oxidase previously demonstrated by the glucosyltransferase inhibitor. Chlorpromazine did indeed block the hyperirritability and resulted in enhancement of the keto amine's effects on the enzyme and lipids. It is possible that the two drugs in combination would be helpful in ameliorating the symptoms due to the cerebroside accumulation that occurs in Gaucher disease. Diazepam also produced a reduced level of glucosyltransferase. A color reaction for chlorpromazine, possibly suitable for quantitative determination in tissues, was accidentally discovered.

Lipids 17:538-543, 1982.
\end{abstract}

Glucocerebroside (glucosyl ceramide) is synthesized from ceramide and UDP-glucose by a glucosyltransferase, EC 2.4.1.80 (1,2). It is also hydrolyzed by a glucosidase to ceramide and glucose (3). In the human genetic disorder Gaucher disease, the glucosidase is inefficient and glucocerebroside accumulates to a great extent. If the manifold symptoms of the disorder are due primarily to the accumulation of the lipid, it may be possible to ameliorate the symptoms by administration of a drug that inhibits the synthesis of the lipid. Hopefully, after an initial period of depletion, the rate of synthesis can be matched to the individual's rate of hydrolysis. This laboratory has described several such inhibitors which work in vitro $(4,5)$ and we now describe some of the effects produced by one of the compounds in young mice. The inhibitor used here, DMP, is an analog of the enzyme product glucocerebroside. The phenyl group in the inhibitor resembles the long aliphatic chain of sphingosine, the decanoylamino group resembles the

\footnotetext{
1 Present address: Molecular Disease Branch, Natl. Heart, Lung and Blood Institute, Bethesda, MD.

2Present address: Technicon Instruments Corp., Tarry town, NY.

Abbreviations: DMP, 2-decanoylamino-3-morpholino-propiophenone; $\mathrm{CPZ}$, chlorpromazine.
}

much longer fatty acid amide found in the naturally occurring lipid, the ketone group resembles the $3-\mathrm{OH}$ of sphingosine, and the morpholine resembles the glucose moiety. Because the ketone group has a beta relationship to the morpholine nitrogen atom, DMP is chemically reactive and it is likely that it inactivates the glucosyltransferase by direct, covalent reaction with the active site.

\section{MATERIALS AND METHODS}

Ceramide:UDP-glucose glucosyltransferase was assayed by a 2-phase liquid scintillation method, in which 5 or $6 \mathrm{mg}$ of homogenized liver was incubated in a plastic counting vial with octanoyl sphingosine as the glucose acceptor $(6,7)$.

Male ICR mice (Harlan Industries, Indianapolis, IN), 24 days old, were maintained for 6 days in our animal room on mouse chow in wire-bottomed cages and $12 \mathrm{hr}$ light/dark cycles. They were divided in to groups of 6-10, matched in average weight and weight distribution, and injected intraperitoneally (ip) with $0.2 \mathrm{ml}$ of saline or $0.2 \mathrm{ml}$ of saline containing $\mathrm{CPZ} \cdot \mathrm{HCl}(10 \mathrm{mg} / \mathrm{kg}$ body wt). After $1 \mathrm{hr}$, half the mice were injected with $0.2 \mathrm{ml}$ saline and the other half were injected with 0.2 or $0.4 \mathrm{ml}$ of $\mathrm{DMP} \cdot \mathrm{HCl}(250$ or $500 \mathrm{mg} / \mathrm{kg})$, freshly dis- 
solved in saline. Thus, each mouse received 2 injections (e.g., the controls received 2 saline injections $1 \mathrm{hr}$ apart, the CPZ-DMP mice received $C P Z$ first, then DMP $1 \mathrm{hr}$ later). At a later point, the livers were removed, washed with cold saline, wiped dry, weighed, cooled on Dry Ice, and stored at $-70 \mathrm{C}$ in groups of 3,4 or 5 .

For enzyme assays, the pooled livers were homogenized in water. For lipid analyses, they were homogenized with hexane/isopropanol $3: 2$ (8) and processed as described separately $(9,10)$. Total lipids were determined gravimetrically with the extract from $0.4 \mathrm{~g}$ liver, washed with conc aq Na sulfate to remove nonlipids (11).

\section{RESULTS}

The initial studies with DMP were carried out with mice from Spartan Research and only the glucosyltransferase activities in liver were measured. Injection of DMP $(250 \mathrm{mg} / \mathrm{kg})$ produced distinct decreases in the enzyme activities, with a maximal decrease in the specific activities of about $48 \%$ in 2-6 hr. Sacrifice at later time-points showed smaller reductions, evidently due to loss of the inhibitor and, probably, to resynthesis of the enzyme. However, by $24 \mathrm{hr}$ after the injection, the enzyme specific activity had risen to $20 \%$ above normal. It was back to normal after a second day.

It was noticed that, shortly after injection, the mice exhibited symptoms of hyperirritability, body tremors and head twitching, as well as abduction of the hind legs. They appeared to be normal after a period of about $3 \mathrm{hr}$. Tests of DMP in vitro and after injection showed (12) that it possesses the ability to inhibit monoamine oxidases, apparently by a covalent in- activation similar to that seen with the glucosyltransferase. To reduce the symptoms of central nervous system stimulation, and to enable us to administer higher doses of DMP, we tried injecting CPZ $1 \mathrm{hr}$ before the DMP. The CPZ did indeed eliminate the hyperactivation effect of DMP without affecting the recovery period ( 3 hr). The unexpected finding (Table 1) was made that $C P Z(10 \mathrm{mg} / \mathrm{kg})$ was as effective as DMP $(250 \mathrm{mg} / \mathrm{kg})$ in lowering the level of glucosyltransferase, even showing the same rebound phenomenon at $25 \mathrm{hr}$. Particularly satisfying was the observation that the two drugs produced additive effects.

Tests with sedating drugs, using mice killed 3 hr after injection, showed $0.997 \mathrm{nmol} / \mathrm{hr}$ of cerebroside synthesized by $6 \mathrm{mg}$ of liver from control mice, a $25 \%$ decrease with $\mathrm{CPZ}$, a $10 \%$ decrease with reserpine $(2.5 \mathrm{mg} / \mathrm{kg})$, and a $14 \%$ decrease with diazepam $(10 \mathrm{mg} / \mathrm{kg})$. Stimulating drugs $(8 \mathrm{mg} / \mathrm{kg}$ D-amphetamine, $8 \mathrm{mg} / \mathrm{kg}$ metrazol) had no effect.

The Spartan mice became unavailable, so we tested several strains of mice for their enzyme levels and reaction to DMP. It was found that none of the strains tested had as high a specific activity as the Spartan mice, nor was the variability between mice lower, even with inbred mice ( $\mathrm{C} 3 \mathrm{H})$. The observed specific activities for cerebroside synthesis by $5 \mathrm{mg}$ of liver were $443 \pm 50$ pmol with Charles River (D-1 outbred albinos, $490 \pm 70$ pmol with Charles River C3H mice, $691 \pm 50$ pmol with Charles River CF-1 mice, and $496 \pm 60 \mathrm{pmol}$ with ICR mice. Although the ICR mice did not have the highest specific activity, they responded a little better to DMP and were used for further tests.

Trials of various doses of DMP with these mice, without $\mathrm{CPZ}$, showed that they appeared normal within $3 \mathrm{hr}$ after injection of 500

TABLE 1

Effect of Chlorpromazine and Decanoylaminomorpholinopropiophenone on Liver Glucosyltransferase of Spartan Mice

\begin{tabular}{|c|c|c|c|c|}
\hline & \multicolumn{4}{|c|}{ Drug in jected } \\
\hline & Controls & $\mathrm{CPZ}$ & DMP & $\mathrm{CPZ}+\mathrm{DMP}$ \\
\hline $\begin{array}{l}\text { 2-hr groups: } \\
\text { Cerebroside formed (nmol } / 6 \mathrm{mg} \text { ) } \\
\text { Inhibition ( } \% \text { below controls) }\end{array}$ & $\begin{array}{c}0.91 \\
-\end{array}$ & $\begin{array}{l}0.49 \\
47\end{array}$ & $\begin{array}{l}0.48 \\
48\end{array}$ & $\begin{array}{l}0.30 \\
67\end{array}$ \\
\hline $\begin{array}{l}\text { 24-hr groups: } \\
\text { Cerebroside formed (nmol/ } 6 \mathrm{mg}) \\
\text { Increase (\% above controls) }\end{array}$ & $\begin{array}{c}0.75 \\
-\end{array}$ & $\begin{array}{c}0.88 \\
18\end{array}$ & $\begin{array}{l}0.90 \\
19\end{array}$ & $4^{1.06}$ \\
\hline
\end{tabular}

aTimes shown are for animals in jected with DMP. All animals were injected $1 \mathrm{hr}$ previously with saline or CPZ. Values shown are averages of 2 values obtained by pooling 2 groups of 3 livers (i.e., 6 mice/group) and assaying for glucocerebroside synthetase. 
$\mathrm{mg} / \mathrm{kg}$; at $750 \mathrm{mg} / \mathrm{kg}$, recovery took $6 \mathrm{hr}$ and, at $1 \mathrm{~g} / \mathrm{kg}$, they recovered within $24 \mathrm{hr}$. All mice seemed quite normal for the next $3 \mathrm{wk}$.

Trials with trifluoperazine, a drug related to CPZ but more potent as an antipsychotic, showed only a $7 \%$ decrease in glucosyltransferase at $10 \mathrm{mg} / \mathrm{kg}$ and the additive effect with DMP was slight. Haloperidol, an antipsychotic drug resembling DMP in structure, produced little or no decrease $3 \mathrm{hr}$ after injecting 5 $\mathrm{mg} / \mathrm{kg}$.

An experiment with $\mathrm{CPZ}$ and DMP was carried out with the ICR mice, which were sacrificed $2 \mathrm{hr}$ after DMP injection at a dosage of $500 \mathrm{mg} / \mathrm{kg}$ (sacrificed $3 \mathrm{hr}$ after CPZ injection). The reduction in glucosyltransferase was not as large as with Spartan mice, but the two drug effects were still additive (Table 2). The body weights were unaffected in this short period of exposure to the drugs, whereas the liver became distinctly enlarged in all three drug-treated groups. However, there was no sign of additivity here.

The effects of CPZ and DMP on glucosyltransferase were found also with female ICR mice, possibly to a greater degree than in males. The depression in enzyme activity (about $42 \%$ for DMP and DMP+CPZ) appeared within about $3 \mathrm{hr}$ and persisted about $3 \mathrm{hr}$, then the overshoot effect (about $41 \%$ ) was visible $23 \mathrm{hr}$ after the initial injection.

Another trial in which the drugs were allowed to act for $5 \mathrm{hr}$ (for DMP) showed that $\mathrm{CPZ}$ could produce a marked increase in liver weight, but here the effect of DMP seemed to be absent (Table 3). Determination of the total lipids in the livers showed that part of the weight increase was due to an increase in the weight of the lipids. The ceramide concentrations also increased, more so than the total lipids, but the cerebroside level decreased. All the lipid changes, like the cerebroside synthetase changes, showed additivity between the two drugs. It was evident that the changes in cerebroside levels showed a parallelism with the drug-induced reduction in glucosyltransferase. The relatively large loss of cerebroside, up to $32 \%$, in just 5-6 hr shows that this lipid undergoes a relatively rapid turnover.

A shorter term study, in which the DMP was allowed to act only $2 \mathrm{hr}$ (Table 4), showed similar, but smaller, changes in ceramide and cerebroside concentrations.

A semiquantitative examination of the liver lipids by thin layer chromatography (TLC), with visual evaluation of the charred spots, revealed that the increased level in liver lipids was due almost entirely to an increase in triglyceride level. Evidently, the two drugs stimulate a very rapid biosynthesis of triglyceride or mobilization from the body to the liver. (However, the solvent that was used for chromatography could not discriminate between triglyceride and dialkyl acyl glycerol, an appreciable component of normal liver.)

It was also noticed, during handling of the mice, that the two drugs produced a marked lowering of body temperature in the mice. $\mathrm{CPZ}$ has previously been noted to weaken the body's ability to control its temperature, in animals and in human patients (13), and the toxicity of the drug depends on the ambi-

TABLE 2

Glucosyltransferase in Livers of ICR Mice after Injection of Chlorpromazine or Decanoylaminomorpholinopropiophenone

\begin{tabular}{|c|c|c|c|c|}
\hline & $\begin{array}{l}\text { Body wt } \\
\text { (g) }\end{array}$ & $\begin{array}{l}\text { Liver wt } \\
\text { (g) }\end{array}$ & $\begin{array}{l}\text { Cerebroside formed } \\
(\mathrm{pmol} / 5 \mathrm{mg})\end{array}$ & $\begin{array}{c}\text { Inhibition } \\
(\%)\end{array}$ \\
\hline Controls & $\begin{array}{l}26.1 \\
25.9(26.1) \\
26.4\end{array}$ & $\begin{array}{l}1.07 \\
1.08(1.09) \\
1.12\end{array}$ & $\begin{array}{l}591 \\
506(540) \\
523\end{array}$ & - \\
\hline CPZ-injected & $\begin{array}{l}25.4 \\
26.9(26.1) \\
26.1\end{array}$ & $\begin{array}{l}1.27 \\
1.40(1.33) \\
1.33\end{array}$ & $\begin{array}{l}514 \\
328(412) \\
395\end{array}$ & 24 \\
\hline DMP-injected & $\begin{array}{l}25.3 \\
26.2(26.1) \\
26.8\end{array}$ & $\begin{array}{l}1.23 \\
1.28(1.21) \\
1.11\end{array}$ & $\begin{array}{l}506 \\
372(398) \\
316\end{array}$ & 26 \\
\hline $\mathrm{CPZ}+\mathrm{DMP}$ & $\begin{array}{l}25.1 \\
26.5(26.0) \\
26.3\end{array}$ & $\begin{array}{l}1.15 \\
1.23(1.21) \\
1.24\end{array}$ & $\begin{array}{l}289 \\
251(263) \\
249\end{array}$ & 51 \\
\hline
\end{tabular}

Values shown are averages from 3 mice, 2 hr after injection of DMP ( $3 \mathrm{hr}$ after injection of $(P Z)$. Values in parentheses are the averages of the 3 measurements. 
TABLE 3

Liver Lipids after Injection of Chlorpromazine and Decanoylaminomorpholinopropiophenone

\begin{tabular}{|c|c|c|c|c|c|c|c|c|}
\hline & \multirow{2}{*}{$\begin{array}{l}\text { Body wt } \\
\text { (g) }\end{array}$} & \multirow{2}{*}{$\begin{array}{l}\text { Liver wt } \\
\text { (g) }\end{array}$} & \multirow{2}{*}{$\begin{array}{l}\text { Lipids } \\
\text { (mg/g) }\end{array}$} & \multirow{2}{*}{$\begin{array}{l}\text { Lipid increase } \\
(\%)\end{array}$} & \multicolumn{2}{|c|}{ Ceramide level } & \multicolumn{2}{|c|}{ Cerebroside level } \\
\hline & & & & & $\mu \mathrm{g} / \mathrm{g}$ & Increase & $\mu \mathrm{g} / \mathrm{g}$ & Decrease \\
\hline Controls & $\begin{array}{l}22.2 \\
22.3\end{array}$ & $\begin{array}{l}1.03 \\
1.06\end{array}$ & $\begin{array}{l}51.3 \\
48.8\end{array}$ & - & $\begin{array}{l}103 \\
105\end{array}$ & - & $\begin{array}{l}38 \\
37\end{array}$ & - \\
\hline CPZ-injected & $\begin{array}{l}22.6 \\
22.3\end{array}$ & $\begin{array}{l}1.19 \\
1.17\end{array}$ & $\begin{array}{l}59.8 \\
57.3\end{array}$ & 17 & $\begin{array}{l}140 \\
120\end{array}$ & $25 \%$ & $\begin{array}{l}35 \\
36\end{array}$ & $6 \%$ \\
\hline DMP-injected & $\begin{array}{l}22.4 \\
22.4\end{array}$ & $\begin{array}{l}1.05 \\
1.03\end{array}$ & $\begin{array}{l}58.5 \\
56.3\end{array}$ & 15 & $\begin{array}{l}194 \\
159\end{array}$ & $69 \%$ & $\begin{array}{l}31 \\
30\end{array}$ & $20 \%$ \\
\hline CPZ + DMP-injected & $\begin{array}{l}22.7 \\
22.4\end{array}$ & $\begin{array}{l}1.18 \\
1.15\end{array}$ & $\begin{array}{l}80.5 \\
72.5\end{array}$ & 53 & $\begin{array}{l}192 \\
167\end{array}$ & $72 \%$ & $\begin{array}{l}26 \\
25\end{array}$ & $32 \%$ \\
\hline
\end{tabular}

Values shown are averages from 5 mice, injected $5 \mathrm{hr}$ prior to sacrifice with DMP (or $6 \mathrm{hr}$ with $\mathrm{CPZ}$ ).

TABLE 4

Ceramide and Cerebroside Levels in the Livers of Control and Treated Groups of ICR Mice

\begin{tabular}{|c|c|c|c|c|c|}
\hline & \multirow{2}{*}{$\begin{array}{c}\text { Liver wt } \\
\text { (g) }\end{array}$} & \multicolumn{2}{|c|}{ Ceramide level $b$} & \multicolumn{2}{|c|}{ Cerebroside level $^{b}$} \\
\hline & & $\overline{\mu \mathrm{g} / \mathrm{g}}$ & Increase & $\mu \mathrm{g} / \mathrm{g}$ & Decrease \\
\hline Controls & 1.09 & $\begin{array}{l}150 \\
117 \\
101\end{array}$ & - & $\begin{array}{l}33 \\
33 \\
32\end{array}$ & - \\
\hline CPZ-injected & 1.33 & $\begin{array}{l}154 \\
132 \\
155\end{array}$ & $20 \%$ & $\begin{array}{l}33 \\
27 \\
22\end{array}$ & $8 \%$ \\
\hline DMP-injected & 1.21 & $\begin{array}{l}171 \\
203 \\
164\end{array}$ & $46 \%$ & $\begin{array}{l}33 \\
29 \\
29\end{array}$ & $7 \%$ \\
\hline $\mathrm{CPZ}+\mathrm{IDMP}$ & 1.21 & $\begin{array}{l}196 \\
203 \\
167\end{array}$ & $54 \%$ & $\begin{array}{l}29 \\
24 \\
24\end{array}$ & $21 \%$ \\
\hline
\end{tabular}

a Liver weights are the averages from 9 mice.

bValues shown are the averages from groups of 3 mice. All were sacrificed $2 \mathrm{hr}$ after injecting DMP ( 3 hr after CPZ).

ent temperature (14). Measurements of rectal temperature in the mice (Fig. 1) revealed that both drugs induced hypothermia in $30 \mathrm{~min}$ or less and that it persisted for at least $5 \mathrm{hr}$. Here the additive effect of the two drugs was apparent only during the first $90 \mathrm{~min}$.

The CPZ effect on glucosyltransferase, unlike that produced by DMP, could not be demonstrated in incubations with liver homogenate, even at a concentration of $0.3 \mathrm{mM}$. Thus, it is possible that the enzyme is inhibited by one or more of the several known metabolites of CPZ. Mixing the liver homogenates from control and CPZ-injected mice gave only the expected intermediate values, indicating an absence of soluble inhibitors in the CPZ- injected mice. This might mean that a CPZ metabolite had combined irreversibly with some of the glucosyltransferase, and the amount of the free metabolite was too low to affect the added normal enzyme.

An interesting side-observation was the finding that CPZ could be seen in the liver extracts after TLC of the cerebroside fraction (using silica gel with chloroform/methanol/water 24:7:1). The CPZ was visible just above the cerebroside pair of bands as a pink spot immediately after spraying with cupric acetate and aq phosphoric acid (15). The color deepened upon heating, instead of charring to the usual gray band. Two $\mu$ g or less of CPZ could be seen readily and it is possible that the 


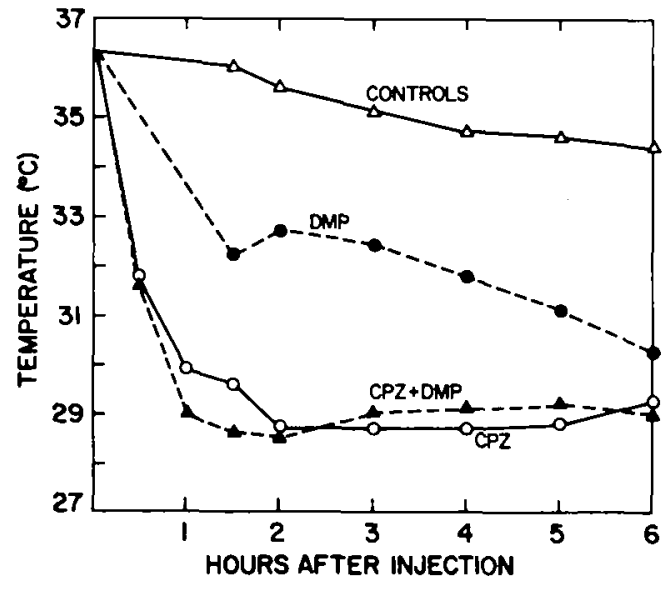

FIG. 1. Rectal temperatures of mice injected with chlorpromazine or decanoylaminomorpholinopropiophenone, or both. Data points are averages from three mice.

method-which seems to show no interference at all-could be useful for quantitative analysis of tissues or blood. A similar color reaction between CPZ and phosphoric acid has been reported for paper chromatograms (16).

\section{DISCUSSION}

The ability of DMP to lower liver cerebroside concentration, through its known effect on ceramide:UDP-glucose glucosyltransferase, is encouraging for our goal of treating Gaucher disease by chemotherapy. The current approach to treatment, injection of normal cerebroside glucosidase obtained at great cost from human placentas, has not proved effective in reversing the progress of the disorder (17). Although the interference with regulation of body temperature by DMP and CPZ is a drawback, this problem is readily handled by CPZ-consuming patients by the use of appropriate clothing and control of body activity.

The effects of DMP and $\mathrm{CPZ}$ in mice on glucosyltransferase and cerebroside could be attributed to some indirect effect of body cooling, but this explanation is improbable because the additivity of the drugs in their biochemical effects is not paralleled by their nonadditivity in reduction of body temperature.

Remarkably many effects on enzyme reactions and physiological phenomena have been demonstrated for CPZ and we can now add the observed reduction in glucosyltransferase and cerebroside, and the accumulation of ceramide. The accumulation of fat in liver has been previously noted in rats (18) and in patients (19) given CPZ chronically. However, ours seems to be the first demonstration that this accumulation appears very quickly, after a single dose of the drug. Experiments with rats given two single (but heavy) does of CPZ have shown a $41 \%$ increase in total phospholipid weight in the liver microsomes within 48 $\mathrm{hr}$ after the initial dose (20). Since CPZ is being given to patients over a relatively long period of time, sometimes at dosage levels as high as ours, one might ask whether there is any effect in these patients on sphingolipid metabolism.

The accumulation of ceramide, seen with both drugs, is presumably due to reduction in its rate of utilization for glucocerebroside synthesis without an accompanying decrement in its rates of synthesis or hydrolysis. This kind of accumulation is seen in the human genetic disorder ceramidosis or Farber's lipogranulomatosis, where the defect is in the rate of hydrolysis. The second major synthetic conversion route for liver ceramide is the reaction with lecithin to form sphingomyelin (21), but this reaction appears to be much slower than ceramide glucosylation, at least in vitro. The rapid rise in ceramide level suggests that it has a relatively high tumover rate in liver. Alternatively, one could postulate a rapid mobilization from the peripheral organs, like triglycerides. Ceramides and triglycerides do resemble one another in their low polarity and in their derivation from fatty acids.

The overshoot effect observed $24 \mathrm{hr}$ after administering the two drugs is not unknown with other inhibitors and is presumably the result of imprecise regulation of enzyme levelsin this case, a temporary overrapid synthesis of glucosyltransferase. This lability in the enzyme level suggests that it has a high turnover rate and is relatively responsive to exogenous influences. This interpretation is consistent with the results of experiments on the effects of protein synthesis inhibitors on the enzyme (22).

It is possible that the large reduction in glucosyltransferase we produced would not be necessary in treating Gaucher disease since the accumulation of cerebroside is relatively slow and it might suffice to produce only a small decrement in its rate of synthesis. In general, it seems that organisms possess somewhat more hydrolase than the corresponding synthetase; that is, there is surplus hydrolase activity. The large reduction in cerebroside glucosidase seen in Gaucher disease probably does not signify so large a decrease in the actual rate of cerebroside breakdown. 


\section{ACKNOWLEDGMENTS}

This work was supported by a grant from the National Institutes of Health, HD 07406. We are indebted to Inez Mason for her assistance. Trifluoperazine was kindly furnished by Smith Kline \& French Labs., Haldol (haloperidol), by McNeil Laboratories.

\section{REFERENCES}

1. Basu, S., Kaufman, B., and Roseman, S. (1973) J. Biol. Chem. 248, 1388-1 394.

2. Morell, P., Costantino-Ceccarini, E., and Radin, N.S. (1970) Arch. Biochem. Biophys. 141, 738-748.

3. Brady, R.O., Kanfer, J., and Shapiro, D. (1965) J. Biol. Chem. 240, 39-43.

4. Vunnam, R.R., and Radin, N.S. (1980) Chem. Phys. Lipids 26, 265-278.

5. Radin, N.S., and Vunnam, R.R. (1981) in Methods in Enzymology (Lowenstein, J.M., ed.) Vol. 72, pp. 673-684, Academic Press, New York, NY.

6. Vunnam, R.R., and Radin, N.S. (1979) Biochim. Biophys. Acta 573, 73-82.

7. Hospattankar, A.V., and Radin, N.S. (1981) Lipids 16, 764-766.

8. Hara, A., and Radin, N.S. (1978) Anal. Biochem. 90, 420-426.

9. Radin, N.S., Deshmukh, G.D., Selvam, R., and Hospattankar, A.V. (1982) submitted for publi- cation.

10. Selvam, R., and Radin, N.S. (1981) Anal. Biochem. 112, 338-345.

11. Radin, N.S. (1981) in Methods in Enzymology (Lowenstein, J.M., ed.) Vol. 72, pp. 5-7, Academic Press, New York, NY.

12. Vunnam, R.R., Bond, D., Schatz, R.A., Radin, N.S., and Narasimhachari, N. (1980) J. Neurochem. 34, 410-416.

13. Borison, H.L., and Clark, W.G. (1967) Adv. Pharmacol. 25, 129-212.

14. Dandiya, P.C., Johnson, G., and Sellers, E.A. (1960) Can. J. Biochem. Physiol. 38, 591-596.

15. Fewster, M.E., Burns, B.J., and Mead, J.F. (1969) J. Chromatogr. 43, $120-126$.

16. Vignoli, L., Gouezo, F., and Morel, M.C. (1962) Bull. Soc. Pharm. Marseille 11, 311-314.

17. Gatt, S., Grabowski, G.A., and Desnick, R.J. (1982) Gaucher Disease: A Century of Delineation and Research, Alan R. Liss, New York, NY.

18. Hormia, M., Hormia, A., and Hakola, P. (1957) Ann. Med. Exp. Biol. Fenniae 35, 316-323.

19. Waitzkin, L., and MacMahon, H.E. (1962) Ann. Intern. Med. 56, 220-232.

20. Ide, H., and Nakazawa, Y. (1980) J. Pharm. Dyn. 3, 612-619.

21. Ullman, M.D., and Radin, N.S. (1974) J. Biol. Chem. 249, 1506-1512.

22. Shah, S.N., and Peterson, N.A. (1971) Biochim. Biophys. Acta 239, 126-131.

[Received February 26, 1982] 